\title{
Ozone Decontamination of Poultry Meat and Biogenic Amines as Quality Index
}

\author{
Raffaella Mercogliano ${ }^{1 *}$, Alessandra De Felice ${ }^{2}$, Nicoletta Murru ${ }^{1}$, Serena Santonicola² and Maria Luisa Cortesi ${ }^{1}$
}

${ }^{1}$ Department of Veterinary Medicine and Food Productions, Faculty of Veterinary Medicine, University "Federico II" of Naples, via F. Delpino 1, 80137 Napoli, Italy ${ }^{2}$ Veterinarisn, University "Federico II" of Naples, via F. Delpino 1, 80137 Napoli, Italy

\begin{abstract}
To assure food safety in poultry meat the European Regulation does not authorize any decontamination treatment. Ozone has a strong oxidizing nature that makes it a useful tool for the inactivation of microorganisms. Aim of this study was to evaluate the effects of an experimental ozone gaseous treatment and production of the biogenic amines putrescine and cadaverine, as freshness index, during the storage of chilled poultry carcasses. Amines were extracted with perchloric acid, derivative with dansyl chloride, separated using a reversed- phase high-performance liquid chromatographic method, and detected by fluorescence. The results showed a reduction of microbial contamination as effect of the experimental ozone treatment of carcasses. In simply chilled poultry meat (Lot C control) a significant increases of putrescine and cadaverine at 15th days of storage. At 20t day higher levels of putrescine $(53,63 \mathrm{mg} / \mathrm{kg}$ ) and cadaverine $(175,20 \mathrm{mg} / \mathrm{kg})$ occurred in Lot $C$ than in treated poultry meat of Lot A. Ozone decontamination resulted in lower levels of putrescine $(32,37 \mathrm{mg} / \mathrm{kg}$ ) and cadaverine $(132,30 \mathrm{mg} / \mathrm{kg})$, and in Lot $A$ the shelf life was 6 days longer than in Lot $\mathrm{C}$. If authorized, an ozone treatment during the storage of chilled poultry meat can induce a reduction of microbial contamination. Putrescine and cadaverine levels appeared to be useful to control the effectiveness of the ozone treatment on meat quality, and may be useful as quality index to highlight the loss of poultry meat freshness, before sensorial meat changes during storage of chilled poultry meat.
\end{abstract}

\section{Keywords: Poultry meat; Ozone treatment; Biogenic amines}

\section{Introduction}

The worldwide poultry meat production and consumption have increased rapidly and, per capita consumption of poultry meat in many parts of the world will continue to grow. Competitive price, the absence of cultural and religious obstacles, and dietary and nutritional properties are the main factors explaining the poultry meat's attractiveness for consumers [1]. Hygiene intervention in the poultry meat processes alone does not lead to safe products, owing to the constant flow of bacteria entering the processing plant and unavoidable cross- contamination. Eradication of pathogens in the livestock, or the rearing of animals that are "Specified Pathogen Free" (SPF), might make relevant contributions, but the SPF system is currently too expensive [2]. Decontamination of meat and poultry carcasses can help to reduce human foodborne infections, and seems to be the only possibility to assure food safety. So many decontamination treatments of the poultry carcasses have been described, which can roughly be divided into three types: chemical, physical and combinations of the two. The problems are that not all of the treatments are applicable in the meat industry, and physical or chemical treatments of poultry carcasses are not allowed in Europe according to certain EU regulations, yet they approved in the USA. Decontamination treatment with ozone has been approved by the U.S. Food And Drug Administration (FDA) Department of Health and Human Services, that has considered ozone as a food additives, recognized as GRAS (Generally Recognized for Safe) substance, and has approved its use in gas phase and water, as a scavenger in processing, storage and processing of food, according to the Good Practices Manufacturing (GMP) (Code of Federal RegulationCFR document 21), as an antimicrobial agent. Ozone treatments for the food decontamination are also permitted in Canada, but the gas concentrations do not exceed the minimum levels technologically necessary. Ozone $\left(\mathrm{O}_{3}\right)$ is a tri-atomic gaseous molecule consisting of three oxygen atoms. It is an allotrope of oxygen much less stable than the diatomic allotrope $\left(\mathrm{O}_{2}\right)$ characterized by strong oxidizing nature that makes it a useful tool for the inactivation of bacteria, fungi and viruses. Ozone first attacks the bacterial membrane at the glycoproteins, glycol lipids, or at certain amino acids such as tryptophan, and then also acts on the sulphydryl groups resulting in disruption of the normal cell. Bacterial death is rapid and often attributed to changes in cell permeability followed by lysis, and the bactericidal effect depends on several factors, such as temperatures, relative humidity, $\mathrm{pH}$ values and presence of organic matter [3]. In food industry ozone is used as sanitizing agent capable of killing numerous microorganisms by oxidizing their cell membranes. It has been proposed as chemical decontamination treatment of poultry carcasses, because it is capable of experimentally extending the shelf life of perishable foods by reducing microbial activity [4]. The use as water-disinfecting agent has not been reported [2] in a superficial disinfectant treatment of chilled poultry carcasses, and neither visual defect to the carcasses, nor sensory off-flavors were shown [4]. Sometimes ozone generators are used in food storage rooms to control the growth of microorganism and the shelf life of products. Ozone represents a public health hazard above concentrations of $100 \mu \mathrm{g} / \mathrm{kg}$, especially when it is applied in production areas, because of high oxidizing potential, that can cause damage in mucus and respiratory tissues [5], but the modern ozone generators can be better controlled the gas emissions in habitat.

*Corresponding author: Raffaella Mercogliano, Department of Veterinary Medicine and Food Productions, Faculty of Veterinary Medicine, University "Federico II" of Naples, via F. Delpino 1, 80137 Napoli, Italy, Tel: +39 0812536062 Fax +39 081458683; E mail: raffaella.mercogliano@unina.it

Received January 15, 2014; Accepted February 25, 2014; Published March 12 2014

Citation: Mercogliano R, Felice AD, Murru N, Santonicola S, Cortesi ML (2014) Ozone Decontamination of Poultry Meat and Biogenic Amines as Quality Index. J Food Process Technol 5: 305. doi:10.4172/2157-7110.1000305

Copyright: @ 2014 Mercogliano R, et al. This is an open-access article distributed under the terms of the Creative Commons Attribution License, which permits unrestricted use, distribution, and reproduction in any medium, provided the original author and source are credited. 
Biogenic Amines (BAs) are organic, basic nitrogenous compounds of low molecular weight [5] that are present in large number of food, including meat and meat products. They are classified in three categories according to their chemical structures. Generally removal of the $\alpha$-carboxyl group from an amino acid leads to the corresponding biogenic amine [6]. The most important BAs in food are putrescine, cadaverine, tyramine, histamine, 2 -phenyl ethylamine and agmatine, produced by decarboxylation of the amino acids ornithine, lysine, tyrosine, histidine, phenylalanine and arginine, respectively. The presence of specific BAs depends on the decarboxylase enzyme, that catalysis the decarboxylation of amino acids, and a transporter responsible for amino acid-BA interchange [7]. Decarboxylation increases survival under stress conditions [8] via the consumption of protons and the excretion of amines and $\mathrm{CO}_{2}$, helping to restore the external $\mathrm{pH}$. BAs production may also offer a way of obtaining energy in the bacteria metabolism. The formation of Bas is primarily a consequence of to the enzymatic decarboxylation of specific amino acids due to microbial enzymes or tissue activity, and their production depends on the availability of free amino acids in food, presence of microbial decarboxylase, conditions that favour enzymatic processes and bacterial growth, such as temperature, $\mathrm{pH}$ and saline and oxygen concentrations [9]. BAs may have a role as indicators of quality and/ or acceptability in some foods [10-12]. The concentration of some BAs (tyramine, putrescine, and cadaverine) normally increase during the processing and storage of meat and meat products, whereas other (spermine and spermidine) decrease or remain constant [6,13-14]. In meat and cooked meat product BAs have been used as quality indexes and indicators of unwanted microbial activity. Quantity of BAs is considered a marker of the level of microbiological food contamination [15]. A combination of putrescine and cadaverine has been suggested as an index of acceptability in fresh meat, because their concentrations increase prior to spoilage and correlate well with the microbial load [16,17]. High cadaverine concentrations are considered clearly indicative of poilage [18]. Poultry surface and meat provide condition suitable especially for growth of microorganisms and thus also for production of BAs $[19,20]$. An increase of BA formation in poultry muscle can occur even during freezing [21]. BA can indicate quality of meat, and more specifically hygienic conditions under which it was processed and stored [22]. It is reported that putrescine, cadaverine and tyramine, could serve as quality indicators of modified atmosphere packaging-stored broiler chicken [23]. Both in white meat (chicken) and red (adult bovine) BA levels are indicators of spoilage because of their susceptibly to proteins degradation, which takes place under appropriate conditions [9]. In fact in chicken muscles there are shorter muscle fibers than in bovine fibers, which can be easily attached by proteolytic enzymes, so this favour the availability of free amino acids, amine precursors. In particular in the white meat quite all the BAs increased, but cadaverine is produced in the greatest quantity, and this is probably ascribable to the high amount of the precursor lysine [9], while increased putrescine levels are often associated to spoilage conditions. Consequently BAs determination in meat is suitable for detecting incipient spoilage and certain amines levels can be related to the freshness of the poultry meat. As quality index of freshness in white meat, the determination of cadaverine and putrescine concentrations could be used to monitor spoilage in white meat $[9,23]$.

Aim of this study was to evaluate the effects of an experimental ozone treatment during the storage of chilled poultry carcasses, and the correlation of BAs production as quality index in poultry meat.

\section{Materials and Methods}

Immediately after slaughter and chilling, 50 broilers, weight 2.5 $\mathrm{kg}$, were collected in a EU authorized slaughterhouse. Lot control $\mathrm{C}$, (25 carcasses), according to the usual methods, were stored in a refrigerated cell equipped with thermograph set to $0-1^{\circ} \mathrm{C}$. To obtain a major decontamination effect, being $\mathrm{O}_{3}$ in the gaseous/ aqueous phases effective against the majority of microorganisms and viruses at relatively low concentrations and short contact time [2-24-26], Lot A (25 carcasses) was previously washed by ozonized water using a concentration of $\mathrm{O} 3 \mathrm{~mL} / \mathrm{L}$, before the gaseous sanitizing treatment. Then the carcasses of Lot $\mathrm{A}$ and control $\mathrm{C}$ were stored in a refrigerated cell, also equipped with video thermograph set to $0-1^{\circ} \mathrm{C}$. In cell of Lot $\mathrm{A}$ a generator of gaseous ozone (OZONET of OXITECH Srl) and a timer, so as to deliver ozone for an interval 60 minutes every 4 hours, on the basis of preliminary bacterial reduction tests on carcasses surfaces, were installed [26,27]. Dimensions of both refrigerated cell were: height $3,60 \mathrm{~cm}$, inches deep $3,24 \mathrm{~cm}$ and length $1,32 \mathrm{~cm}$. Temperature values and ozone air levels inside the cells was monitored using a probe and a display, positioned on the outside of the cells, along the time of experiment. At 0th , 4th , 6th , 8th , 11th , 14th and 20th days of storage three carcasses of each batch were collected, and 2 aliquots, consisting of the breast muscle (predominantly white fibers) and limbs (prevalence of red fibers), have been separately subjected to the determination of the $\mathrm{pH}$ for each sample. Then sensory and analysis of BAs were carried out on a pool of the two aliquots combined.

\section{Sensorial analysis}

A panel of 5 people, who have consistently followed the analysis, used an evaluation table and a score between 0 and 4 . In sensory parameters evaluation general coloration, staining of the worst points and percentage of the discolored surface were considered.

\section{Physical -chemical analysis}

The $\mathrm{pH}$ evaluation was carried out by incision of the muscles of the regions of the breast and limb. Determination of $\mathrm{pH}$ was measured with a $\mathrm{pH}$ meter (Microprocessor $\mathrm{pH}$ Meter,Hanna Instruments).

\section{Analysis of biogenic amines}

Reagents: Solvents and reagents were of analytical or HighPerformance Liquid Chromatography (HPLC) grade. The biogenic amine standard of putrescine dansyl-hydrochloride (PUT) and Cadaverine Dansyl-Dihydrochloride (CAD) were obtained from Sigma (St. Louis, MO).

\section{HPLC system}

Analyses were carried out using a HPLC system (JASCO), equipped with a quaternary pump (JASCO 2089 plus), and a $20 \mu \mathrm{L}$ loop, combined with a Jasco integrator, and an 821-Fp fluorescence detector. Detection of amines was accomplished at an excitation wavelength of $350 \mathrm{~nm}$ and an emission wavelength of $520 \mathrm{~nm}$. Separation was performed on a reversed- phase C18 Luna column $5 \mu \mathrm{m} 518$ (Phenomenex Inc., Torrance CA) (250 mm lenght x $4.6 \mathrm{~mm}$ internal diameter, and $5 \mu \mathrm{m}$ particle size) with a 3 X $4 \mathrm{~mm}$ Security Guardcartridge guard column) (Phenomenex Inc., Torrance CA).

\section{Sample preparation}

Perchloric acid 0.2 M was added and mixed to homogenized chicken meat according to Tamin [28]. The extract was centrifuged at $4000 \mathrm{rpm}$ for $20 \mathrm{~min}$ in three steps. Surfactant was collected and 
divided into portions of $2 \mathrm{~mL}$. The sample was centrifuged at 12.000 $\mathrm{rpm}$ for $10 \mathrm{~min}$. Finally amine extract was reacted with dansyl- chloride overnight at $25^{\circ} \mathrm{C}$ and extracted with $2 \mathrm{~mL}$ diethyl ether.

\section{Chromatography}

The extract was concentrated to dryness, solved in $100 \mu \mathrm{L}$ of methanol and 20 micro litres of methanol were injected into the HPLC system. The mobile phase was water (A) and methanol (B). Before use the solvents were filtered through $0.1 \mu \mathrm{m}$ and degasser under vacuum. Amines was eluted with a flow rate of $2 \mathrm{~mL} / \mathrm{min}$ by the gradient: $35 \%$ water and $65 \%$ methanol for $7 \mathrm{~min}, 100 \%$ methanol in $15 \mathrm{~min}$ at a flow rate of $0.8 \mathrm{~mL} / \mathrm{min}$. Quantification of amines. The linearity and the quantification of the instrumental response were checked by injecting five different concentrations ranging from 0.6 up to $200 \mu \mathrm{g} / \mathrm{L}$ of a PUT and CAD standard mixture.

\section{Results}

In poultry meat of Lot $\mathrm{A}$ and $\mathrm{C} \mathrm{pH}$ and $\mathrm{BA}$ values, as a function of storage time, were reported in Figures 1,2 and 3. Ozone concentrations inside the cells ranged from $0.82 \mathrm{ppm}$ (minimum value) to $1.2 \mathrm{ppm}$ (maximum value), under these conditions the results showed the following considerations:

a. in the sensory evaluation a discoloration of poultry carcasses at 14th days have occurred in the carcasses of Lot control, while in the treated carcasses of Lot A an acceptable sensory quality occurred until to 20th day;

b. $\mathrm{pH}$ analysis at 20th day, in both carcasses of Lot control $\mathrm{C}$ and

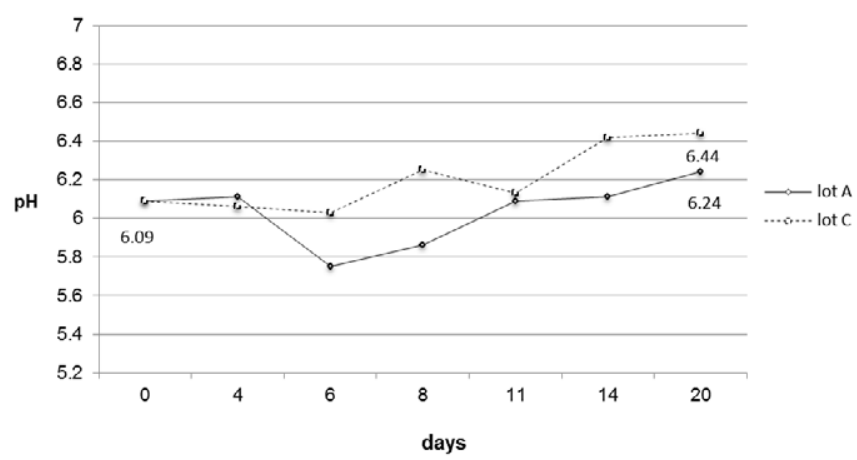

Figure 1: $\mathrm{pH}$ breast values during the storage of ozone treated poultry carcasses of Lots control $\mathrm{C}$ and Lot $\mathrm{A}$.

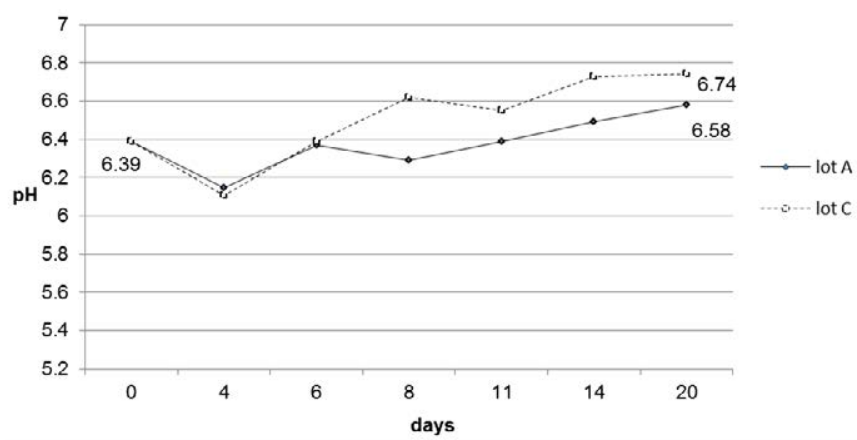

Figure 2: $\mathrm{pH}$ leg values during the storage of ozone treated poultry carcasses of Lot control $\mathrm{C}$ and Lot $\mathrm{A}$.

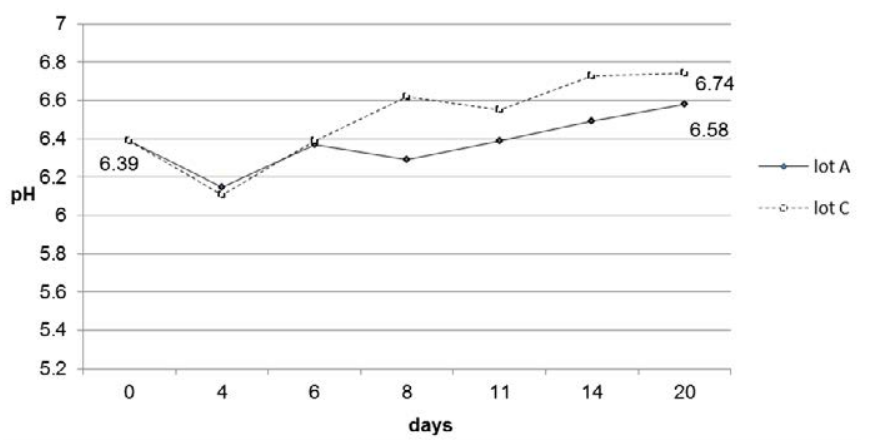

Figure 2: $\mathrm{pH}$ leg values during the storage of ozone treated poultry carcasses of Lot control $\mathrm{C}$ and Lot $\mathrm{A}$.

A, showed values more acid (6.44 Lot C, and 6.24 Lot A) in the chicken breast than in the leg, probably because of the prevailing anaerobic metabolism of white fibers, and prevailing aerobic metabolism of the red fibers. During storage a gradual increase of the $\mathrm{pH}$ values in meat $[29,30]$, obtained from carcasses simply chilled, has been occurred, and it has been related to BAs production, in agreement with the data of Balamatsia [24]. In ozone treated meat of Lot $\mathrm{A}$ a shelf life 6 days longer than those of Lot control C. Even if values of $\mathrm{pH}$ were slight reduced, it is possible that more acid $\mathrm{pH}$ values and lower levels of BAs have better controlled the microbiological quality of poultry treated carcasses. Increasing the ranges of gaseous $\mathrm{O} 3$ injection on the camera might cause a further reduction of BA levels.

c. BAs are considered indicators of quality of raw materials and process hygiene in meat and BA levels depend on the specific micro flora and the bacterial count of food [31].

According to Balamatsia [24] high levels of PUT (53,63 mg/ $\mathrm{kg})$ and CAD $(175,20 \mathrm{mg} / \mathrm{kg})$, characterized by a growing trend and significant increases to 15th days, were in chilled poultry meat of Lot control C, while the decontamination effect of ozone, associated with chill temperatures, resulted in a lower levels of PUT $(32,37 \mathrm{mg} / \mathrm{kg})$ and CAD $(132,30 \mathrm{mg} / \mathrm{kg})$ in ozone treated poultry meat.

\section{Discussion}

Consumption of poultry meat frequently causes food-borne diseases. In food industry the presence of bacteria biofilms is a significant problem, because of the environmental persistence of bacteria and their resistance to desiccation, UV radiation and other antimicrobial treatments. Since the processes used for the cleaning and disinfection of equipment and poultry surfaces can reduce, but not always eliminate bacteria and pathogens contamination, in Europe there is an increased interest in developing decontamination methods applicable to meat. As decontamination ozone treatments can limit the surface contamination of poultry carcasses, and can be a valuable aid to GMP in poultry slaughterhouses, if an integrated approach to the problem "decontamination" treatment is considered. In fact the ozone treatment of the poultry carcasses inside chilled cells may show positive effects on the bacterial contamination and shelf life of the poultry meat [2]. For pathogens control in meat production, as decontamination treatment and auxiliary tools, EU Reg./2004/852 and EU Reg./2004/853 authorize only the use of ozonized potable water. Furthermore Italian National Committee for Food Security (CNSA, 27/10/2011) experts have expressed a favorable opinion also regarding 
gaseous ozone treatment of chambers of seasoning and / or storage areas of cheeses in the absence of food. Several indicators have been proposed for the evaluation of meat quality (volatile bases, nucleotides break-down, volatile acidity, but all are limited [10-17,32,33,37-39]. Quality sensory analysis is, undoubtedly, a widely accepted as the most rapid method to detect quality of fresh meat, but it is subjective [10]. Furthermore, it would be desirable to identify parameters most effective to evaluate meat's shelf life, before the effects of the spoilage changes of sensory quality [34]. In particular, European expert group BIOHAZ recognized a strong correlation between the BAs presence in food and the quality of raw materials, in terms of freshness and biological safety. Biogenic amines, histamine, putrescine, tyramine, tryptamine, 2-pheniylethylamine and cadaverine, can be formed during storage of fresh meat [10,35-36]. Since they are metabolites of microbial activity, they are considered to be useful indices of freshness of meat, in contrast polyamines spermine and spermidine are naturally occurring amines in fresh meat [19,29-35]. Levels of all amines increase with increasing putrefaction except spermidine and spermine, which decrease during putrefaction of poultry carcasses. Biogenic amines histamine, tyramine, and phenyl ethylamine remain low for approximately $24 \mathrm{~h}$, after which they rose sharply to high levels at $72 \mathrm{~h} \mathrm{[19].} \mathrm{PUT} \mathrm{and} \mathrm{CAD}$ also exhibited a common response pattern, but in poultry carcasses these amines remain low through the first $24 \mathrm{~h}$, and then rise to high levels, and they plateau at $48 \mathrm{~h} \mathrm{[19].} \mathrm{In} \mathrm{the} \mathrm{decontamination} \mathrm{treatments}$ is important to respect the GMP optimizing the ozone concentrations and monitoring the storage conditions of poultry carcasses. In particular ozone, as storage applications, should be allowed to dissipate prior to workers entering the area treated. Data regarding the ozone decontamination treatment of poultry carcasses showed that in the experimental poultry carcasses treatment the ozone gas was dissipated inside the freezer cells, thus the workers were not exposed to harmful concentrations of the oxidizing agent, and PUT and CAD levels, as indicators of freshness/spoilage, were correlate to microbial quality of poultry meat in treated and also no-treated carcasses. BIOHAZ GROUP recommends the validation of methods of analysis of BA in foods, to achieve a flawless control on the food quality. Analysis of biogenic amine levels in treated poultry carcasses was more indicative of the sensorial analysis; consequently they could effectively evaluate meat quality in an ozone gaseous treatment. Furthermore in poultry meat. Detecting the only levels of BAs as PUT and CAD may be a valuable and sufficiently rapid method for monitoring the effectiveness of a decontamination treatment. In conclusion, if authorized, an ozone treatment during the storage of chilled poultry meat can induce a reduction of microbial contamination. The results showed a reduction of microbial contamination as effect of the ozone treatment during the storage of chilled poultry carcasses. Evaluation of only PUT and CAD levels, as freshness index, was useful to highlight the loss of meat freshness before sensorial changes, and appeared to be useful to control the effectiveness of the ozone treatment and meat quality during the storage of chicken meat.

\section{References}

1. Petracci M, Cavani C (2012) Muscle growth and poultry meat quality issues. Nutrients 4: 1-12.

2. Bolder NM (1997) Decontamination of meat and poultry meat. Trend Food SciTech 8: 221-227.

3. Moore G, Griffith C, Peters A (2000) Bactericidal properties of ozone and its potential application as a terminal disinfectant. J Food Prot 63: 1100-1106.

4. Rice RG, Graham D, Sopher CD (2001) Proceeding of the international ozone association pan American group. In Annual conference, advances in ozone technology, California.
5. Bodmer S, Imark C, Kneubühl M (1999) Biogenic amines in foods: histamine and food processing. Inflamm Res 48: 296-300.

6. Bardócz S (1995) Polyamines in food and their consequences for food quality and human health. Trend Food Sci Tech 6: 341-346.

7. Linares DM, Martín MC, Ladero V, Alvarez MA, Fernández M (2011) Biogenic amines in dairy products. Crit Rev Food Sci Nutr 51: 691-703.

8. Rhee JE, Kim KS, Choi SH (2005) CadC activates pH-dependent expression of the Vibrio vulnificus cadBA operon at a distance through direct binding to an upstream region. J Bacteriol 187: 7870-7875.

9. Vinci G, Antonelli ML (2002) Biogenic amines: quality index of freshness in red and white meat. Food Control 13: 519-524.

10. Mietz JL, Karmas E (1997) Polyamine and histamine content of rockfish, salmon, lobster and shrimps as an indicator of decomposition. J Assoc Offic Anal Chem 61: 139-145.

11. Veciana-Nogues MT, Hernandez-Jover T, Marine-Font A, Vidal-Carou MC (1995) Liquid chromatographic method for determination of biogenic amines in fish and fish products. J AOAC Int 78: 1045-1050.

12. Carou MC (1999) Biogenic amine and polyamine contents in meat and meat products. J Agr Food Chem 45: 2089-2012.

13. Ruiz-Capillas C, Moral A (2001) Production of biogenic amines and their potential use as quality control indices for hake (Merluccius merluccius, L.) stored in ice. J Food Sci 66: 1030-1032.

14. Ten Brink B, Damink C, Joosten HM, Huisin't Veld JH (1990) Occurrence and formation of biologically active amines in foods. Int J Food Microbiol 11: 73-84.

15. Halász A, Baráth A, Simon-Sarkadi L, Holzapfel W(1994) Biogenic amines and their production by microorganisms in food. Trend Food Sci Tech 5: 42-49.

16. Leuschner RG, Kurihara R, Hammes WP (1998) Effect of enhanced proteolysis on formation of biogenic amines by lactobacilli during Gouda cheese ripening Int J Food Microbiol 44: 15-20.

17. Slemr J, Beyermann K (1985) Concentration profiles of diammines in fresh and aerobically stored pork and beef. J Agr Food Chem 33: 336-339.

18. Edwards RA, Dainty RH, Hibbard CM (1985) Putrescine and cadaverine formation in vacuum packed beef. J Appl Bacteriol 58: 13-19.

19. Wortberg B, Woller R (1982) Quality and freshness of meat and meat products as related to their content of biogenic amines. Fleischwirtsch 62: 1457-1463.

20. Tamin NM, Doerr JA (2003) Effect of putrefaction of poultry carcasses prio to rendering on biogenic amine production. J Appl. Poultry Res 12: 456-460.

21. Moreira AP, Giombelli A, Labanca RA, Nelson DL, Glória MB (2008) Effect of aging on bioactive amines, microbial flora, physico-chemical characteristics, and tenderness of broiler breast meat. Poult Sci 87: 1868-1873.

22. Bunkova L, Bunka F, Klcovskà M, Mrkvicka V (2010) Formation of biogenic amines by Gram-negative bacteria isolated from poultry skin. Food Chem 121: 293-206.

23. Rokka M, Eerola S, Smolander M, Alakomi HL, Ahvenainen R (2004) Monitoring of the quality of modified atmosphere packaged broiler chicken curs stored in different temperature conditions. Biogenic amines as quality-indicating metabolites. Food Contr 15: 601-607.

24. Balamatsia CC, Paleologos EK, Kontominas MG, Savvaidis IN (2006) Correlation between microbial flora, sensory changes and biogenic amines formation in fresh chicken meat stored aerobically or under modified atmosphere packaging at 4 degrees $\mathrm{C}$ : possible role of biogenic amines as spoilage indicators. Antonie Van Leeuwenhoek 89: 9-17.

25. Gorman BM, Sofos JN, Morgan JB, Schmidt GR, Smith GC.(1995) Evaluation of hand-trimming, various sanitizing agents, and hot water spray-washing as decontamination interventions for beef brisket adipose tissue . J Food Prot 58 : 899-907.

26. Kim JG, Yousef AE, Dave S (1999) Application of ozone for enhancing the microbiological safety and quality of foods: a review. J Food Prot 62: 10711087

27. Murray BK, Ohmine S, Tomer DP, Jensen KJ, Johnson FB, et al. (2008) Virion disruption by ozone-mediated reactive oxygen species. J Virol Methods 153 74-77. 
Citation: Mercogliano R, Felice AD, Murru N, Santonicola S, Cortesi ML (2014) Ozone Decontamination of Poultry Meat and Biogenic Amines as Quality Index. J Food Process Technol 5: 305. doi:10.4172/2157-7110.1000305

Page 5 of 5

28. da Silva MV, Gibbs PA, Kirby RM (1998) Sensorial and microbial effects of gaseous ozone on fresh scad (Trachurus trachurus). J Appl Microbiol 84: 802810.

29. Tamim NM, Bennett LW, Shellem TA, Doerr JA (2002) High-performance liquid chromatographic determination of biogenic amines in poultry carcasses. $J$ Agric Food Chem 50: 5012-5015

30. Hernàndez-Jover $T$, Izquierdo-pulido $M$, Veciana-Nogùes $M T$, Vidal-Carou M C(1997a) Effect of starter cultures on biogenic amine formation during fermented sausage production. J Food Prot 60: 825-830.

31. Mercogliano R1, De Felice A, Chirollo C, Cortesi ML (2010) Production of vasoactive amines during the ripening of Pecorino Carmasciano cheese. Vet Res Commun 34 Suppl 1: S175-178.

32. Min JS, Lee SO, Jang A, Lee M, Kim Y (2007) Production of biogenic amines bymicroflora inoculated in meats. Asian-Australian J Anim Sci 17: 1472-1478.

33. Veciana-Nogues MT, Marine-Font A, Vidal-Carou M C (1997) Biogenic amines ashygienic quality indicators of tuna. Relationships with microbial counts, ATP- related compounds, volatile amines and organoleptic changes. J Agr Food Chem 45, 6: 2036- 2041

34. Durlu-Özkaya F, Ayhan K, Vural N (2001) Biogenic amines produced by Enterobacteriaceae isolated from meat products. Meat Sci 58: 163-166.

35. Silva CMG, Beatriz M, Glorìa MBA (2002) Bioactive amines in chicken breast andthigh after slaughter and during storage at $4^{\circ} \pm 1^{\circ} \mathrm{C}$ and in chicken-based meat products. Food Chem 78: 241-248.

36. Gloria MBA, Daeschel, MA, Craven C, Hildebrand K S (1999) Histamine and other biogenic amines in albacores tuna . J Aquat Food Prod Tech 8: 55-69.

37. Lima AS, Gloria MBA (1999) Aminas bioativas em alimentos. Bol. SBCTA 33: 70-79

38. Nakamura M, Wada Y, Sawaya H, Kawabata T (1979) Polyamine content in fresh andprocessed pork. J Food Sci 44 2: 515-523.

39. Yano Y, Kataho N, Watanabe M, Nakamura T, Asano Y (1995) Changes in the concentration of biogenic amines and application of tyramine sensor during storage of beef. Food Chem 54: 155-159. 